\title{
Development and Validation of a Rapid Stability- Indicating HPLC Method for Determination of Carbamazepine in Pure and Dosage Forms
}

\author{
RAGAA EL SHEIKH ${ }^{1}$, AYMAN A GOUDA ${ }^{1 *}$, WAFAA S. HASSAN ${ }^{2}$, \\ HESHAM HASHEM ${ }^{2}$, MOHAMMED ALI ${ }^{1}$ and NASSER F. KANDIEL ${ }^{3}$
}

${ }^{1}$ Chemistry Department, Faculty of Science, Zagazig University, Zagazig, 44519, Egypt

${ }^{2}$ Pharmaceutical Analytical Chemistry Department, Faculty of Pharmacy, Zagazig University, Zagazig, Egypt

${ }^{3}$ Makkah Community College, Umm Al-Qura University, Makkah, Saudi Arabia

aymangouda77@gmail.com

Received 19 May 2016/ Accepted 4 June 2016

\begin{abstract}
A new, simple, rapid and accurate stability-indicating HPLC method was developed and validated for quantitative determination of carbamazepine (CBMZ) in pure and dosage forms. An isocratic HPLC method, using a $\mathrm{C}_{18}$ reversed phase column $(150 \mathrm{~mm} \times 4.6 \mathrm{~mm}$ i.d., particle size $5 \mu \mathrm{m})$ with isocratic binary mobile phase consisting of methanol and water $(70: 30, \mathrm{~V} / \mathrm{V})$, was investigated to separate the drug from its stress degradation products. The flow rate was $1.5 \mathrm{~mL} \mathrm{~min}{ }^{-1}$ at ambient temperature and photo diode array (PDA) detector was used at $285 \mathrm{~nm}$ for detection. The elution time of CBMZ was found to be $2.324 \pm 0.003$ minutes. The developed method was validated for system suitability, linearity, accuracy, precision, limits of detection and quantitation, specificity, stability and robustness. Stability tests were done through exposure of the analyte solution for five different stress conditions: Reflux with $1.0 \mathrm{~mol} \mathrm{~L}^{-1}$ hydrochloric acid $(\mathrm{HCl})$, reflux with $1.0 \mathrm{~mol} \mathrm{~L}^{-1}$ sodium hydroxide $(\mathrm{NaOH})$, reflux with $30 \%$ hydrogen peroxide $\left(\mathrm{H}_{2} \mathrm{O}_{2}\right)$, exposure to ultra violet radiation (UV) radiation and heating. The calibration curve was found to be linear with the equationy $=0.19677 \mathrm{X}-0.306$, with a correlation coefficient of $\left(\mathrm{R}^{2}=0.9999\right)$ over a concentration range of 2.0-24 $\mu \mathrm{gmL}^{-1}$. The limits of detection and quantification were 0.02 and $0.062 \mu \mathrm{gmL}^{-1}$, respectively. The recovery value of this method is $99.80 \%$ and the reproducibility is with in 1.23 .
\end{abstract}

Keywords: Carbamazepine, Rapid stability indicating LC-method, $\mathrm{C}_{18}$ column, Method validation, Stress degradation, Dosage forms

\section{Introduction}

Carbamazepine (CBMZ), 5- $H$-dibenze[b,f]azepine-5-carboxamide (Figure 1), is widely prescribed as an anticonvulsant, antiepileptic and antimanic drug. Carbamazepine is an iminostilbene derivative used for more than three decades as the antiepileptic drug of first choice for the treatment of trigeminal neuralgia and also for both generalizedand partial 
seizures, due to rapid control of excessive cerebral electrical discharges and lower incidence of acute and chronic toxicity ${ }^{1}$. Carbamazepine is official in british pharmacopeia ${ }^{2}$ as it was determined by liquid chrpomatographic (LC) method.

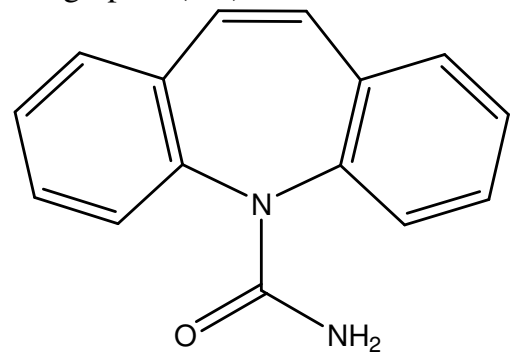

Figure 1. The chemical structure of carbamazepine (CBMZ).

Various techniques have been reported for the assay of CBMZ in pharmaceutical dosage forms and biological fluids, including high-performance liquid chromatography (HPLC) with ultra violet or photo diode detection ${ }^{3-12}$, high-performance thin layer chromatography (HPTLC) $)^{13}$, LC-mass spectrometry methods ${ }^{14-16}$, fluorescence polarization assay $(\mathrm{FPA})^{17,18}$, gas chromatography with mass spectrometry ${ }^{19-21}$, micellar electro kinetic capillary chromatography (MECC) ${ }^{22}$, chemiluminescence ${ }^{23,24}$, spectrofluorimetry $^{25}$, FT-Raman spectroscopy $^{26}$, flow-injection ${ }^{27}$ and spectrophotometry ${ }^{28-37}$ have been reported for the detection of CBMZ and its metabolites.

A literature survey reveals that there is only one previous method dealing with stability indicating methods for determination of $\mathrm{CBMZ}^{9}$ but this method includes some drawbacks such as too long separation time (14 minutes) and lower sensitivity. Therefore the aim of this study is to find an inexpensive, new, sensitive, simple, accurate, precise and rapid stability indicating fully validated chromatographic method applying isocratic mode for determination of CBMZ in bulk powder and tablets and to overcome the problems in all previously reported chromatographic methods as long time of analysis and expensive detectors as shown in Table 1.

Table 1. Chromatographic methods reported for the determination of CBMZ in pharmaceuticals

\begin{tabular}{|c|c|c|c|c|c|}
\hline \multicolumn{3}{|c|}{ Chromatographic conditions } & \multirow[b]{2}{*}{$\begin{array}{l}\text { LOD } \\
\mu \mathrm{g} \mathrm{mL}^{-1}\end{array}$} & \multirow[b]{2}{*}{$\begin{array}{l}\text { Rang } \\
\mu \mathrm{g} \mathrm{mL}\end{array}$} & \multirow{2}{*}{ Reference } \\
\hline Mobile phase & $\begin{array}{l}\text { Flow rate } \\
{\mathrm{mL} \min ^{-1}}\end{array}$ & Detection & & & \\
\hline $\begin{array}{l}\text { Acetonitrile:water } \\
(75: 25, \mathrm{v} / \mathrm{v})\end{array}$ & 1.0 & $\mathrm{UV}$ at $285 \mathrm{~nm}$ & 0.055 & $0.2-2.0$ & [3] \\
\hline $\begin{array}{l}\text { (28:72, v/v) Acetonitrile: } 0.02 \\
\text { M sodiumphosphate buffer } \\
\text { (pH 7.8) }\end{array}$ & 1.0 & $\mathrm{UV}$ at $230 \mathrm{~nm}$ & 0.018 & $5.0-25.0$ & [4] \\
\hline $\begin{array}{l}\text { Acetonitrile-Milli-Q grade } \\
\text { water }(30: 70, \mathrm{v} / \mathrm{v})\end{array}$ & 1.0 & $\mathrm{UV}$ at $220 \mathrm{~nm}$ & 0.05 & $0.25-25$ & [5] \\
\hline Methanol and water $(50: 50, \mathrm{v} / \mathrm{v})$ & 1.0 & $\mathrm{UV}$ at $285 \mathrm{~nm}$ & 0.16 & $0.5-40$ & [6] \\
\hline $\begin{array}{l}\text { Methanol-water-acetic acid } \\
(65: 34: 1)\end{array}$ & 1.0 & $\mathrm{UV}$ at $285 \mathrm{~nm}$ & 0.166 & $0.1-5.0$ & [7] \\
\hline $\begin{array}{l}\text { Acetonitrile:isopropyl } \\
\text { alcohol: phosphate buffer } \mathrm{pH} \text { : } \\
3(36: 15: 49)\end{array}$ & 1.2 & $\mathrm{UV}$ at $220 \mathrm{~nm}$ & 0.05 & $0.1-8.0$ & [8] \\
\hline Methanol - water(57:43\% v/v) & 1.0 & PDA at $280 \mathrm{~nm}$ & 0.2 & $1.0-200$ & [9] \\
\hline
\end{tabular}




\begin{tabular}{|c|c|c|c|c|c|}
\hline $\begin{array}{l}\text { Ethyl acetate-toluene- } \\
\text { methanol }(5.0+4.0+1.0 \\
\mathrm{v} / \mathrm{v} / \mathrm{v})\end{array}$ & & $\begin{array}{l}\text { Densitometri- } \\
\text { canalysisat } \\
285 \mathrm{~nm}\end{array}$ & $16.7 \mathrm{ng} \mathrm{spot}^{-1}$ & $\begin{array}{l}100-600 \\
\text { ng spot }^{-1}\end{array}$ & [13] \\
\hline $\begin{array}{l}\text { Acetonitrile, methanol and } \\
\text { formic acid }(0.1 \%)(10: 70: 20 \text {, } \\
\mathrm{v} / \mathrm{v})\end{array}$ & & at $m / z 237.05$ & $0.722 \mathrm{ngmL}^{-1}$ & & [14] \\
\hline $\begin{array}{l}\text { Water/acetonitrile/acetic acid } \\
(69.5: 30: 0.5, \mathrm{v} / \mathrm{v} / \mathrm{v})\end{array}$ & 0.4 & $m / z 237 \rightarrow 194$ & $5.0 \mathrm{ngmL}^{-1}$ & $\begin{array}{l}5.0-2000 \\
\text { ngmL }^{-1}\end{array}$ & [15] \\
\hline Nitogen as carrier gas & 2.0 & FID & 0.75 & $2.0-30$ & [20] \\
\hline Nitogen as carrier gas & 20 & FID & & & [21] \\
\hline Methanol and water $(70: 30, \mathrm{v} / \mathrm{v})$ & 1.5 & PDA at $285 \mathrm{~nm}$ & 0.02 & $2.0-24$ & $\begin{array}{l}\text { Proposed } \\
\text { work }\end{array}$ \\
\hline
\end{tabular}

\section{Exeprimental}

HPLC: Shimadzu LC-20AD model equipped with UV-detector SPD-20 Asystem (Tokyo, Japan). The $\mathrm{pH}$ measurements were made on a Hanna $\mathrm{pH}$-meter equipped with a combined glass-calomel electrode (Portugal) (HI: 9321).

\section{Chemicals and reagents}

HPLC grade methanol and water were purchased from LAB-SCAN, Analytical Sciences (Gliwice, UL, Sowinskiego, Poland). $\mathrm{NaOH}, \mathrm{HCl}$ and $30 \% \mathrm{H}_{2} \mathrm{O}_{2}$ were purchased from Sigma-Aldrich (St. Louis, MO, USA). Carbamazepine raw material was obtained from Universal Industrial Pharmaceutical Co. (Unipharm) (El-Obour City,Cairo, Egypt).

\section{Pharmaceutical dosage forms}

Mazemaltablets contain $400 \mathrm{mg}$ CBZM per tablet and were produced by Universal Industrial Pharmaceutical Co. (Unipharm) (El-Obour City,Cairo, Egypt). Tegretol tablets contain $200 \mathrm{mg}$ CBZM per tablet and were produced byNovartis Pharmaceuticals, Canada Inc.

\section{Chromatographic conditions}

The chromatographic separation was performed using ODS-3 Intersil C18(150 $\mathrm{mm} \times 4.6 \mathrm{~mm})$, $5.0 \mu \mathrm{m}$ particle size column; the column temperature was maintained at $25 \pm 2{ }^{\circ} \mathrm{C}$. The Auto sampler utilized methanol as a rinse solution, the total run time was 5.0 minutes. The elution quaternary pump ran an isocratic flow using mobile phase consisting of a mixture of methanol and water in the ratio $(70: 30 \% \mathrm{v} / \mathrm{v})$ at a flow rate of $1.5 \mathrm{~mL} \mathrm{~min}^{-1}$. The eluate was monitored at $285 \mathrm{~nm}$ using UV-detector. The retention time of the drug was found to be $2.324 \pm 0.003 \mathrm{~min}$. The injection volume was $10 \mu \mathrm{L}$. Methanol was used as diluent during the standard and test samples preparation.

\section{Preparation of stock and standard working solutions}

A stock solution of CBMZ (200 $\left.\mu \mathrm{gmL}^{-1}\right)$ was prepared by dissolving $20 \mathrm{mg}$ of CBMZ in methanol in $100 \mathrm{~mL}$ volumetric flask, then shake and sonicate for $10 \mathrm{~min}$ till completely dissolved and then, complete the volume to $100 \mathrm{~mL}$ with methanol. The working standard solutions were prepared by diluting aliquots of stock solution with methanol to obtain final concentrations ranging from 2.0 to $24 \mu \mathrm{gmL}^{-1}$. Working solution of the drug was stable for one week.

\section{Construction of calibration curve}

Aliquots of standard solution, ranging from 2.0 to $24 \mu \mathrm{g} \mathrm{mL}{ }^{-1}$ were prepared in a series of $10 \mathrm{mLvolumetric}$ flasks. $10 \mu \mathrm{L}$ was injected into the instrument. Detection was performed at 
wavelength $285 \mathrm{~nm}$. The calibration graph was constructed by plotting the peak areas obtained at the wavelength $285 \mathrm{~nm}$ versus the corresponding injected concentrations.

\section{Procedure for dosage forms}

Twenty tablets were weighed, finely powderedandan accurately weighed amount of the powdered tablets equivalent to $20 \mathrm{mg}$ of $\mathrm{CBMZ}$ was dissolved in $50 \mathrm{~mL}$ of methanol, sonicated for 10 minand the solution was filtered through a $0.45 \mu \mathrm{m}$ membrane filter and then the final solution was completed to volume with methanol in $100 \mathrm{~mL}$ measuring flask. The procedure was then completed as mentioned above under the general procedure.

\section{Stability tests}

Forced degradation studies were performed to provide an indication of the stability-indicating properties and specificity of the method. Intentional degradation was attempted using acid, base, hydrogen peroxide, thermaland UV-radiation. A degradation sample was prepared by dissolving $20 \mathrm{mg}$ of CBMZ in $100 \mathrm{~mL}$ methanol through shaking and sonication. Then $10 \mathrm{~mL}$ of this solution was taken in each of three $50 \mathrm{~mL}$ round bottomed flasks to perform the first three degradation tests. To the first flask, $10 \mathrm{~mL}$ of $1.0 \mathrm{~mol} \mathrm{~L}^{-1} \mathrm{HCl}$ was added for acidic degradation. To the second flask, $10 \mathrm{~mL}$ of $1.0 \mathrm{~mol} \mathrm{~L}^{-1} \mathrm{NaOH}$ was added for basic degradation. To the third flask and $10 \mathrm{~mL}$ of $30 \%(\mathrm{v} / \mathrm{v}) \mathrm{H}_{2} \mathrm{O}_{2}$ was added for oxidative degradation. All the three flasks were refluxed forabout $2.0 \mathrm{~h}$. After completing degradation treatments, samples were allowed to cool to room temperature and treated as follows: The $\mathrm{pH}$ values of the first and second flasks were neutralized with $1.0 \mathrm{~mol} \mathrm{~L}^{-1} \mathrm{NaOH}$ and $1.0 \mathrm{~mol} \mathrm{~L}^{-1} \mathrm{HCl}$, respectively. To the third flask $1.0 \mathrm{~N}$ sodium bisulfite solution was added to destroy $\mathrm{H}_{2} \mathrm{O}_{2}$. The volume of all the three flasks was adjusted to $50 \mathrm{~mL}$ with methanol. Suitable aliquots of resultant degradation samples were taken and subjected to analysis after suitable dilutions with methanol against the control samples (which lacked the degradation treatment).

For thermal degradation, CBMZ powder was dispersed ontoa Petri-dish and left in oven at $45{ }^{\circ} \mathrm{C}$ for $2.0 \mathrm{~h}$ then the solution was prepared from it in a concentration of $200 \mu \mathrm{gmL}^{-1}$ using methanol as solvent.

For degradation through UV-radiation $2.0 \mathrm{~mL}$ of the sample was retained inthe UV radiation from 5.0 to 60 minutes and then the radiated solution diluted with methanol to $10 \mathrm{~mL}$, then finally injected into the LC and compared with the control sample.

\section{Method validation}

The methods were validated according to the International Conference on Harmonization Guidelines $^{38}$ for validation of analytical procedures.

\section{Results and Discussion}

\section{System suitability}

The conditions affecting the chromatographic performance of CBMZ were carefully studied in order to recognize the most suitable chromatographic system. So, the optimum chromatographic performances were achieved viausing isocratic mobile phase composed of methanol: water(70:30) adjusted to $\mathrm{pH} 7.0$, injection volume $10 \mu \mathrm{L}$, column temperature $25{ }^{\circ} \mathrm{C}$, detection wavelength $285 \mathrm{~nm}$ and flow rate $1.5 \mathrm{~mL} \mathrm{~min}^{-1}$. The results of three runs indicate high system suitability (Table 2 ). There tention time $\left(t_{R}\right)$ value of CBMZ was $2.324 \pm 0.003$ minutes. The RSD of peak area was $0.62 \%$. 
Table 2. System suitability and regression data

\begin{tabular}{ll}
\hline \multicolumn{1}{c}{ Parameters } & \multicolumn{1}{c}{ Results } \\
\hline System suitability & $2.324 \pm 0.003$ \\
$\mathrm{t}_{\mathrm{R}} \pm \mathrm{SD}$, min & 10943 \\
$\mathrm{~N}$ & 5.123 \\
$\mathrm{k}$ Linearity and regression data & \\
Linearity range, $\mu \mathrm{gmL}^{-1}$ & $2.0-24$ \\
Detection limit, $\mu \mathrm{gmL}^{-1}$ & 0.02 \\
Quantitation limit, $\mu \mathrm{gmL}^{-1}$ & 0.062 \\
Slope (b) $\pm \mathrm{RSD}$ & $19.677 \pm 0.144$ \\
Intercept (a) $\pm \mathrm{RSD}$ & $-0.306 \pm 0.532$ \\
Coefficient of determination $\left(\mathrm{R}^{2}\right)$ & 0.9999 \\
\hline
\end{tabular}

${ }^{a}$ Theoretical values for $t$ and fat confidence limit at $95 \%$ confidence level and five degrees of freedom $(p=0.05)$ are 2.179 and 3.84 , respectively

\section{Selectivity and specificity of the method}

The resulted peak after tablet analysis is found to be homogeneous and there are no coeluting peaks indicating specificity of the method. Comparison between the chromatogram of the raw CBMZ and that of extracted CBMZ from tablets indicates that the excipients in the formulation did not interfere with the determination of CBMZ (Figure 2). Each of sixteen pharmaceutical substances was simultaneously injected with CBMZ (Table 3) for examination of specificity of the method. Only dapoxetine $\mathrm{HCl}$ was found to inter fere with the method.

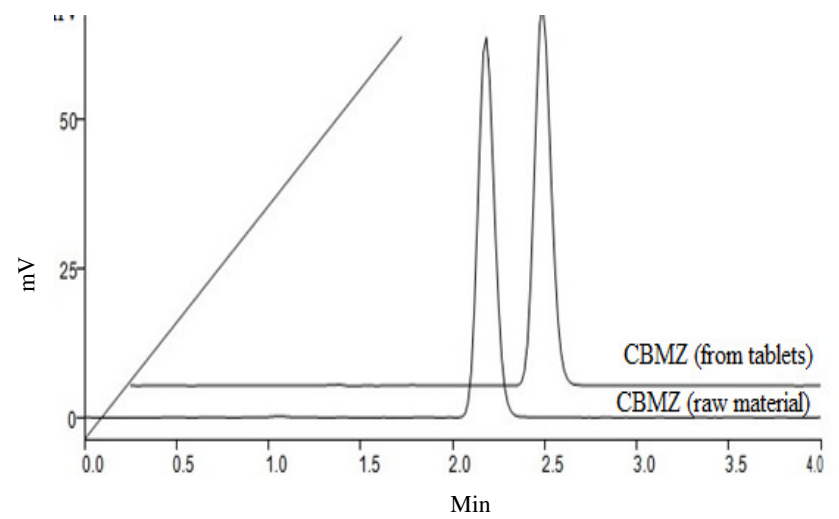

Figure 2. Chromatograms of $\left(20 \mu \mathrm{gmL}^{-1}\right) \mathrm{CBMZ}$ from raw material and tablets

Table 3. Specificity of the proposed method

\begin{tabular}{cccc}
\hline & Not interfered & & Interfered \\
\hline LevocetrizineHCl & Oxeladinecitrate & LoperamideHCl & DapoxetineHCl \\
Montelukastsodium & Ofloxacin & Clopidogrelbisulphate & \\
Paracetamol & Febuxostat & Roflumilast & \\
Ibuprofen & Mosapridecitrate & Asenapinemaleate & \\
Citalopram $\mathrm{HBr}$ & Econazol Nitrate & Chlorocresol & \\
BambuterolHCl & Hydrocortisone & & \\
& acetate & & \\
\hline
\end{tabular}




\section{Stability of the analytical solution and stability tests}

The results (Figure 3) of stress degradation indicate that CBMZ is strongly affected with refluxwith $\mathrm{H}_{2} \mathrm{O}_{2}$. Reflux with $\mathrm{NaOH}$ led to degradation of CBMZ, but the effect here is weaker than that in cases of $\mathrm{H}_{2} \mathrm{O}_{2}$. Much degradation was not observed in CBMZ under stress conditions like reflux with $\mathrm{HCl}$, exposure to $\mathrm{UV}$ radiation and heat. There was no interference with the peak of the intact drug indicating that themethod is stability indicating. The full run time for separation of theintact CBMZ from its degradants is about 5.0 minutes which is very short comparing with the previously reported stability-indicating HPLCmethods for determination of $\mathrm{CBMZ}^{9}$. Stability of the standard solution was studied by injection of the prepared solution at periodic intervals into the chromatographic system up to about 5.0 days. The results indicate that the RSD of the peak area was within 1.07\%.

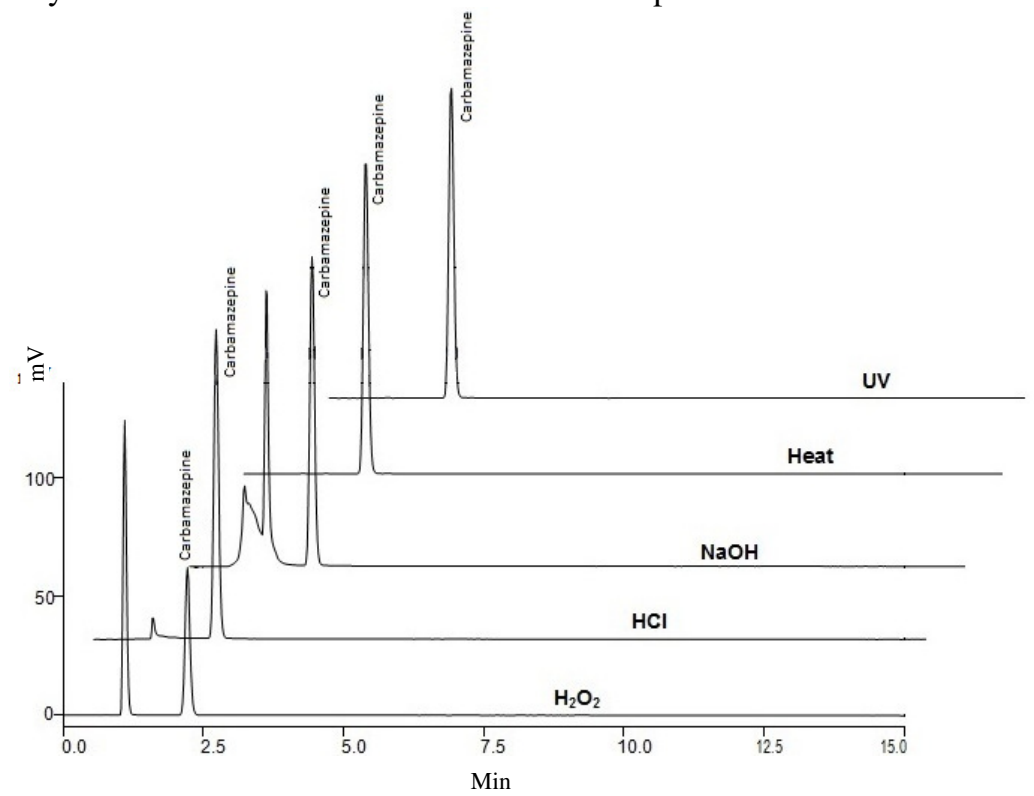

Figure 3. Separation of $\left(20 \mu \mathrm{gmL}^{-1}\right)$ CBMZ from its degradants after different stress degradation conditions

\section{Linearity}

The 12 concentrations of CBMZ solution ranging from $2.0-24 \mu \mathrm{gmL}^{-1}$ were analyzed. The graph of the peak area against concentration proved linear in the range of $2.0-24 \mu \mathrm{gmL}^{-1}$ and the linearity equation is: $\mathrm{Y}=19.677 \mathrm{X}-0.306$ and the regression coefficient $=0.9999$. The limit of detection (LOD) is defined as the injected quantity giving $\mathrm{S} / \mathrm{N}$ of 3.0 (in terms of peak height) and was found to be $0.02 \mu \mathrm{g} \mathrm{mL} \mathrm{m}^{-1}$. The limit of quantification (LOQ) is defined as the injected quantity giving $\mathrm{S} / \mathrm{N}$ of 10 (in terms of peak height) and was found to be $0.062 \mu \mathrm{g} \mathrm{mL}^{-1}$ (Table 2).

\section{Reproducibility and precision of the method}

Results (Table 4 ) show that there were high intra- and inter-day precisions $(\leq 1.01 \%)$. Intraday precision was assessed by injection of the standard solution at three concentrations five times during a day. The same was done for inter-day precision test except that the injection of the samples was every day for five days. 
Table 4. Reproducibility and precision $(n=5)$

\begin{tabular}{ccccccc}
\hline $\begin{array}{c}\text { Injected } \\
\text { amount } \\
\left(\mu \mathrm{gmL}^{-1}\right)\end{array}$ & $\begin{array}{c}\text { Observed } \\
\text { amount } \pm \\
\text { S.D. }\end{array}$ & $\begin{array}{c}\text { RSD, } \\
\%^{*}\end{array}$ & $\begin{array}{c}\text { Accuracy, } \\
\%^{* *}\end{array}$ & $\begin{array}{c}\text { Observed } \\
\text { amount } \pm \\
\text { S.D. }\end{array}$ & $\begin{array}{c}\text { RSD, } \\
\%^{*}\end{array}$ & $\begin{array}{c}\text { Accuracy, } \\
\%^{* *}\end{array}$ \\
\hline 2 & $1.99 \pm 0.016$ & 0.80 & 99.50 & $1.98 \pm 0.02$ & 1.01 & 99.0 \\
20 & $20.10 \pm 0.007$ & 0.037 & 100.51 & $20.04 \pm 0.084$ & 0.42 & 100.20 \\
24 & $24.02 \pm 0.038$ & 0.158 & 100.07 & $23.98 \pm 0.057$ & 0.24 & 99.90 \\
\hline
\end{tabular}

\section{Accuracy and application}

${ }^{*} R S D(\%)=$ S. D. $\times 100 /$ mean

Analysis of CBMZ in Mazemal and Tegretol tablets by the propsed method showed high accuracy with mean recoveries of $99.30 \pm 0.48 \%$ and $99.70 \pm 0.61 \%$, respectively (Table 5). The results were compared with a reported method ${ }^{9}$. The calculated values of $f$ and $t$ indicate that there is no significant difference between both methods.

Table 5. Statistical analysis of results obtained by the proposed method applied on tablets compared with a reported method

\begin{tabular}{cccc}
\hline & Proposed method $^{\mathrm{a}}$ & & ${\text { Reported } \text { method }^{9}}^{9}$ \\
\cline { 2 - 4 } & Mazemal tablets & Tegretol tablets & \\
\hline $\mathrm{n}$ & 5 & 5 & 9 \\
Mean recovery & 99.30 & 99.70 & 100.03 \\
\pm SD & 0.61 & 0.48 & \pm 0.53 \\
t R.S.D\% & 0.61 & 0.48 & \pm 0.53 \\
Variance & 0.37 & 0.23 & 0.28 \\
S.E & 0.27 & 0.21 & 0.18 \\
$t$-value & 0.20 & 0.1 & \\
$F$-value $^{\mathrm{b}}$ & 1.32 & 1.22 & \\
\hline
\end{tabular}

${ }^{a}$ Average of five determinations $(n=5) .{ }^{b}$ Theoretical values for $t$ and fat confidence limit at $95 \%$ confidence level and five degrees of freedom $(p=0.05)$ are 2.179 and 3.84 , respectively

\section{Robustness of the method}

The robustness of the present method was evaluated in the terms of temperature, flow rate, content of $\mathrm{MeOH}$ in mobile phase, wavelength of detection and injection volume (Table 6). The slight variations in the examined factors had no significant effect on the shape of the peak. The results co-efficient of variation (C.V.\%) indicate that the method ismore sensitive to changes in $\mathrm{MeOH} \%$, wavelength and flow rate than changesin the other factors. Compared with retention times ( $t_{R}$-values), peak areas were more affected with the slight changes in the chromatographic conditions.

Table 6. Robustness of the proposed method

\begin{tabular}{|c|c|c|c|c|c|}
\hline $\begin{array}{l}\text { Changes } \\
\text { factors }\end{array}$ & Temp. ${ }^{\circ} \mathrm{C}$ & $\begin{array}{l}\text { Flow rate, } \\
\mathrm{mL} \mathrm{min}^{-1}\end{array}$ & $\mathrm{MeOH}, \%$ & $\begin{array}{l}\text { Wavelength of } \\
\text { detection nm }\end{array}$ & $\begin{array}{c}\text { Injected } \\
\text { Volume, } \mu \mathrm{L}\end{array}$ \\
\hline Changes & $\begin{array}{c}23, \\
25 \text { and } 27 \\
\end{array}$ & $\begin{array}{c}1.45, \\
1.50 \text { and } 1.55\end{array}$ & $\begin{array}{c}68, \\
70 \text { and } 72 \\
\end{array}$ & $\begin{array}{c}282, \\
285 \text { and } 288 \\
\end{array}$ & $\begin{array}{c}9.90, \\
10 \text { and } 10.1\end{array}$ \\
\hline $\begin{array}{c}\text { Tested } \\
\text { parameter }\end{array}$ & $\begin{array}{c}\text { Peak } \\
\text { area }\end{array}$ & $\begin{array}{c}\text { Peak } \\
\text { area }\end{array}$ & $\begin{array}{c}\text { Peak } \\
\text { area }\end{array}$ & $\begin{array}{c}\text { Peak } \\
\text { area }\end{array}$ & $\begin{array}{c}\text { Peak } \\
\text { area }\end{array}$ \\
\hline C.V. (\%) & 1.72 & 2.02 & 2.74 & 0.37 & 1.80 \\
\hline
\end{tabular}




\section{Conclusion}

A valid and rapid stability-indicating HPLC-method for quantification of CBMZ in pure form and tablets was established. Compared with the published chromatographic methods, this method represents a strong reduction of the analysis time and it is considered as a stability indicating method. The full run time for separation of the intact CBMZ from its degradantsis about 5.0 minutes which is very short comparing with the previously published work (14 minutes). With the proposed method a satisfactory separation of CBMZ from the degradation products, extended linear range and rapid analysis time were carried out. Ahigh recovery of CBMZin tablets was achieved. The proposed method ensured a precise and accurate determination of CBMZ in tablet formulations and is a stability-indicating method. No inter ference from the excipients was noticed.

\section{References}

1. Tsatsakis A M, Psillakis T K, Tzatzarakis M, Kourtopoulos H and Paritsis N, Clin Chim Acta, 1997, 263(2), 187-195; DOI:10.1016/S0009-8981(97)00057-0

2. British Pharmacopoeia, Her Majestry's Stationary Office, Monographs: Medicinal and Pharmaceutical Substances, London, Volume I \& II, 2009, electronic version.

3. Tatar Ulu S, Turk J Pharm Sci., 2006, 3, 123-139.

4. Yuan X, Jun H W and Mc Call J W, Anal Lett., 2003, 36(6), 1197-1210; DOI:10.1081/AL-120020153

5. Demirkaya F and Kadioglu Y, FABAD J Pharm Sci., 2005, 30, 78-82.

6. Mowafy H A, Alanazi F K and El Maghraby G M, Saudi Pharm J., 2012, 20(1), 2934; DOI:10.1016/j.jsps.2011.04.003

7. Đorđević S, Kilibarda V andStojanović T, Vojnosani Presgl., 2009, 66(5), 347-352.

8. Ezzeldin E, Shahat A A and Basudan O A, Life Sci J., 2013, 10(4), 2159-2163.

9. $\quad$ Srinivasa R K and Belorkar N, J Adv Pharm Res., 2010, 1, 36.

10. Budakova L, Brozmanova H, Grundmann M and Fischer J, J Sep Sci., 2008, 31(1), 1-8; DOI:10.1002/jssc.200700253

11. Dzodic P, Zivanovic L, Protic A, Ivanovic I, Velickovic-Radovanovic R, pasici M, Lukici S and Zivanovici S, J Serb Chem Soc., 2012, 77(10), 1423-1436; DOI:10.2298/JSC120106084D

12. Ferreira A, Rodrigues M, Falcão A and Alves G, Chromatogr., 2016, 79, 581; DOI: 10.1007/s10337-016-3063-7

13. Patel R B, Patel M R, Bhatt K K and Patel B G, Chromatogr Res Int., 2011, 2010, 1.

14. Van Rooyen G F, Badenhorst D, Swart K J, Hundt H K, Scanes T and Hundt A F, $J$ Chromatogr B Anal Technol Biomed Life Sci., 2002, 769(1), 1-7; DOI:10.1016/S1570-0232(01)00590-6

15. Zhu Y, Chiang H, Wulster-Radcliffe M, Hilt R, Wong P, Kissinger C B and Kissinger P T, J Pharm Biomed Anal, 2005, 38(1), 119-125; DOI:10.1016/j.jpba.2004.11.058

16. Miao X S and Metcalfe C D, Anal Chem., 2003, 75(15), 3731-3738; DOI:10.1021/ac030082k

17. Wilimowska J, Gomółlka E, Pasich A, Jenner B and Szpak D, Przegl Lek., 2005, 62(6), 595-588.

18. Steijns LS, Bouw J and Van der Weide J, Ther Drug Monit., 2002, 24(3), 432-435.

19. Minkova G and Getova D, Methods Find Exp Clin Pharmacol., 2001, 23, 481-485.

20. Kadioglu Yand Demirkaya F, Chromatogr., 2007, 66, 169.

21. Liu F, Wu Y and Zou B, Sepu., 1991, 9, 64-65. 
22. Lancas F M, Sozza M A andQueiroz M E C, J Anal Toxicol., 2003, 27, 304-308.

23. Lee S H, Li M and Suh J K, Anal Sci., 2003, 19(6), 903; DOI:10.2116/analsci.19.903

24. Xiong X, Zhang Q, Xiong F and Tang Y, Fenxi Shiyanshi., 2009, 28, 56-59.

25. Huang C, He Q and Chen H, J Pharm Biomed Anal, 2002, 30, 59-65.

26. Auer M E, Griesser U J and Sawatzki J, J Mol Struct., 2003, 661-662, 307-317; DOI:10.1016/j.molstruc.2003.09.002

27. Comoglu T, Gonul N, Sener E, Dal A and Tuncel M, J Liq Chromatogr Relat Technol., 2006, 29, 2677-2680; DOI:10.1080/10826070600923225

28. Najib F M and Mustafa M S, Malays J Anal Sci., 2014, 18(3), 491.

29. Frag E Y Z, Zayed M A, Omar M M, Elashery S E A and Mohamed G G, Arab J Chem., 2012, 5(3), 375-382.

30. Jayanna B K, Devaraj T D and Gowda N, Indian J Drugs, 2014, 2(3), 132-135.

31. Abdulrahman S A M, Basavaiah K, Revanasiddappa H D and Vinay K B, Malay J Pharm Sci., 2010, 8, 1-17.

32. Basavaiah K and Abdulrahman S A M, Arabian J Chem., 2014, 7(3), 297-305; DOI:10.1016/j.arabjc.2010.11.001

33. Rao G R and Murty S S N, Eastern Pharm., 1982, 25, 111-112.

34. Agrawal Y K, Giridhar R and Menon S, Indian J Pharm Sci., 1989, 51, 75-77.

35. Zaidan T A and Saeed T S, Iraqi Nat J Chem., 2012, 46, 199-214.

36. Borse M P and Mulgund S V, Der Pharm Lett., 2015, 7(11), 272-279.

37. Tambe H J and Mulgund S V, World J Pharm Pharm Sci., 2015, 4, 1200.

38. International Conference on Harmonization of Technical Requirements for Registration of Pharmaceuticals for Human Use, 2005, ICH Harmonized Tripartite Guideline, Validation of Analytical Procedures: Text and Methodology, Q2(R 1), Complementary Guideline on Methodology dated 06 November ICH, London; 1996. 